Editorial

\title{
Migration-Led Institutional Change in Urban Development and Planning
}

\author{
Robert Barbarino ${ }^{1, *}$, Charlotte Räuchle ${ }^{2}$ and Wolfgang Scholz ${ }^{1}$ \\ ${ }^{1}$ School of Spatial Planning, TU Dortmund University, 44227 Dortmund, Germany; \\ E-Mails: robert.barbarino@tu-dortmund.de (R.B.), wolfgang.scholz@tu-dortmund.de (W.S.) \\ 2 Institute of Geographical Science, Department of Earth Science, Free University Berlin, 12249 Berlin, Germany; \\ E-Mail: charlotte.raeuchle@fu-berlin.de \\ * Corresponding author
}

Submitted: 9 April 2021 | Published: 27 April 2021

\begin{abstract}
The migration-city-nexus has become central in migration and urban studies alike. This 'local turn' has not only initiated a rethinking of the local level as an independent level of migration policy-making but also broadened the discourse on how migration processes actually change cities. Therefore, the thematic issue at hand seeks to understand how migration-led development processes in cities promote and shape institutional change, and which actors transform policies, structures, and discourses on migration in different settings. It questions how migration-related issues in urban development are being handled and transformed by local state and civil society actors. With 11 empirical articles on local negotiations of migration in urban development in different settings, this thematic issue applies an institutional change perspective on local migration policy-making to contribute to a broader understanding of migration-led development in both urban and migration studies. When it comes to clearly capturing migration-led institutional change in urban development and planning, the contributions demonstrate great heterogeneity. They reveal that research on migration-led institutional change still has many biases and is very dependent on theoretical perspectives, positionalities of researchers, and the local context of the case studies.
\end{abstract}

\section{Keywords}

institutional change; migration; urban development; urban governance

\section{Issue}

This editorial is part of the issue "Migration-Led Institutional Change in Urban Development and Planning" edited by Robert Barbarino (TU Dortmund University, Germany), Charlotte Räuchle (Free University Berlin, Germany) and Wolfgang Scholz (TU Dortmund University, Germany).

(C) 2021 by the authors; licensee Cogitatio (Lisbon, Portugal). This editorial is licensed under a Creative Commons Attribution 4.0 International License (CC BY).

\section{Introduction}

Highly dynamic migration movements put the role of cities in migration policy-making around the globe on the agenda and question how migration-related issues in urban development are being handled by local government agencies, street-level bureaucrats, migrant organisations, and Social Movements. This thematic issue seeks to understand how migration-led development processes in cities promote and shape institutional change at a local level, and which actors transform policies, structures, and discourses on migration in urban development in different contexts.
With the 'local turn,' cities have become central in migration and urban studies, and a broad range of concepts and empirical studies deal with the migrationcity-nexus. It led to a rethinking of the local level as an independent level of policy-making rather than merely implementing national policies, illustrating the heterogeneity of the local level (see e.g., Caponio, Scholten, \& Zapata-Barrero, 2018; Dekker, Emilsson, Krieger, \& Scholten, 2015; Jørgensen, 2012; Scholten, 2016). Frequently, these studies address topics like migrants' access to local labour markets, refugee reception and asylum, the socio-spatial organisation of integration policy-making, as well as migrant self-representation 
in the urban society, to name just a few. However, the extent to which 'migration' leads to institutional change at the urban scale remains an open question, even if first studies reveal migration-induced change, e.g., in urban administrations (see e.g., Lang, 2020).

To frame 'institutional change,' this thematic issue suggests, first, to refer to new institutionalism from political sciences. This perspective allows defining institutions in the sense of policies, laws, or regulations as formal political institutions. Institutional change occurs not only on different governance scales but is also locally embedded in specific historical and geographical contexts ( $\mathrm{Hu}$ \& Yang, 2019; Sorensen, 2011; Streeck \& Thelen, 2005, p. 9). Second, notions of sociological institutionalism help to explain governance in the context of urban planning, referring to institutions in a broader sense as formal rules, and informal norms and practices, which both structure actions and form routines (González \& Healey, 2005, p. 2058; Healey, 1999, 2007). Both approaches locate transformation and local governance innovation between state and civil society actors. Thus, institutional change, as this thematic issue understands it, develops in the gaps between established policies or rules and their interpretation and enforcement (Mahoney \& Thelen, 2010 , p. 14). Considering this, the contested implementation of new routines in informal norms and practices, or formal political institutions (like policies, laws, and regulations) enables institutional change.

Therefore, this thematic issue builds on a broader understanding of institutions to analyse migration-led institutional change in different local settings. The contributions in this issue show a connection between governance actors and their locally embedded actions. We claim that for a better understanding of local migration policy dynamics, research should encompass a strong focus on migration-induced change in urban development and planning. With 11 empirical articles on local negotiations of migration in urban development in different settings, we make a first attempt at an institutional change perspective on local migration policymaking and aim to contribute to a broader understanding of migration-led institutional change in both urban and migration studies.

\section{Content}

The articles in this thematic issue contribute to filling the research gaps illustrated above. They are based on empirical case studies in different national and local settings, with a focus on the Global North.

Hanhörster and Ramos Lobato (2021) open the discourse on migration-led institutional change in urban development by focusing on migrants' access to the rental housing market in Germany. The authors look at the influence of institutional housing providers as potential preventers of institutional discrimination, their internal routines by allocating flats and how they, indirectly, contribute to the (re)production of socio-spatial inequality. It is not only a general housing shortage which restricts migrants' access to housing in Germany; these institutional housing providers also play a key role. In contrast to other European countries, discrimination remains a taboo in Germany, making it even more difficult to enter into a meaningful dialogue on how migration-led change in the sense of promoting equal opportunities can be achieved in the housing market.

In a similar vein, Vergou, Arvanitidis, and Manetos (2021) have been exploring refugees' access to housing, the corresponding policy responses, and the effects on socio-spatial segregation, by comparing three small and medium-sized Greek cities. The authors shed light on the interplay between municipalities and various local initiatives and NGOs in refugee allocation, and their influence on institutional change. As a result of the decentralisation of refugee accommodation and the new regulatory powers of municipalities in this context, the municipalities have developed different ways of handling refugee accommodation.

Desille and Sa'di-Ibraheem (2021) study the actors, discourses, and administrative practices used to increase the current mobilities of people (Jewish immigrants, investors, tourist visitors, and evicted residents) and explore their impact on the continuity of the settlercolonial regime in pre-1948 Palestinian urban spaces which became part of Israel. The city of Acre/Akkon, receiving the vast majority of new Jewish immigrant families in the last decades, serves as a case study. Their findings reveal a dramatic change in the attempts to Judaize the city: Mobility policies through neoliberal means have not only been instrumental in continuing the processes of displacement and dispossessions of Palestinians in the so-called "mixed city" but have also recruited new actors, and created new techniques and opportunities to accelerate the Judaization of the few Palestinian spaces left.

In contrast, Gruber's (2021) study deals with the challenges of youth migration between Eastern and Central Europe, taking as a case study an EU-funded INTERREG programme dealing with problems of a declining population and outmigration of a young and educated population. It is perceived as a loss of human capital on the one side and immigration as a burden on the other. The project aimed to analyse how far transnational cooperation can offer potentials for sustainable institutional change to support local stakeholders to better govern population decline and migration measures. The article makes clear that even if official institutions are open to migration-led change, short-term projects cannot contribute to sustainable institutional changes. Instead, there is a need for long-lasting activities to influence institutions.

Fernández-Suárez and Espiñeira (2021) shed light on innovative pro-migrant policies at the local level, taking the new municipalist governments of Madrid and Barcelona (between 2015 and 2019) as case studies. The authors examine the municipal room for manoeuvre in migration policy-making in austere Spain and 
discuss innovative political measures to protect irregular migrants locally. Here, the new municipalist governments supported, e.g., access to social services and healthcare, and the granting of work permits to bypass illegality and criminalisation. The authors conclude that even if cities can gain certain legal options on how the control of migration is enforced, there are, however, constant tensions between political will and institutional constraints.

The article by Bund and Gerhard (2021) comparatively analyses institutional and structural conditions for local variations in integration strategies in four midsized German cities. Depending on the cities' share of migrants, financial and economic capacities, and knowledge assets, the local handling of migrants differs. Different actors from the municipalities or civil society can become the driving force in welcoming migrants. This makes the need for localised tailor-made approaches even more apparent. The article shows that even if financial capacities and socio-economic performance of municipalities and their residents have a great impact on the implementation of migration-related projects, it can be compensated by well-established networks and/or strong political will by local leaders.

The next article by Jahre (2021) discusses the implementation of a new urban policy in 20 different neighbourhoods of Berlin close to large refugee shelters, from the aspect of postmigrant spatial justice. In 2017, Berlin established the 'integration management programs' (BENN) as a response to the growing challenges local authorities faced due to refugee migration. The author analyses the BENN programme in the historical context of Berlin's participation and migration policies, detecting both continuities and changes in the local governance of migration.

Nettelbladt's (2021) article investigates how municipal governments negotiate far-right contestations through the format of citizens' dialogues at a neighbourhood scale in Cottbus, Germany. It analyses the reactionary responses to migration-led societal transformations in cities and their effects on institutional change in participation. The article shows how agonistic and communicative approaches in participatory urban governance can normalise arguments of far-right politics and disrupt the possibility of democratic dialogue. The study concludes that only a careful reconfiguration of participation practice challenges racist language, 'anti-elite' sentiments, and the emotionalisation of societal problems.

Budnik, Grossmann, and Hedtke (2021) also examine the role of social conflicts in the context of migration and discuss the relationship between conflicts and institutional change, taking the contested construction of a Syriac-Orthodox church in a small town in Germany in the 1990s as a case study. The article shows that conflicts ascribed to migration can fuel local institutional change. However, migration-led institutional change occurs indirectly, in small steps, and with ambivalent normative implications as a result of long-lasting processes.
The authors conclude the importance of external and endogenous factors that lead to an iterative change in specific local social and historical contexts.

Zhuang's (2021) article contributes insights from immigrants' suburban settlements in Toronto, Canada, and analyses how various immigrant communities have shaped suburban neighbourhoods. The article sheds light on the role of municipal planning in managing diversity and in facilitating inclusive community-building. Despite the neighbourhoods being vital places serving the social, cultural, and economic interests of their inhabitants, the municipalities are rather reluctant towards developing a permissive policy environment to support ethnic communities' place-making efforts. The case studies reveal that municipalities might lack a thorough understanding of the needs of the ethnic communities in these neighbourhoods.

Finally, Huning, Droste, and Gliemann (2021) look at institutional transformation in German planning administrations to promote intercultural opening in urban planning. Here, 'intercultural opening' means overcoming access barriers based on cultural norms and open participation in urban planning for underrepresented groups. The authors reconfirm that bureaucratic structures and terminology do not adequately address the needs of the target groups characterised by, e.g., missing language skills. One major problem is that planning departments often do not have direct contact with the population, including migrants, since participation is often outsourced to private planning bureaus.

\section{Synopsis and Outlook}

In sum, all empirical contributions to this thematic issue demonstrate great heterogeneity when it comes to clearly identifying migration-led institutional change in urban development and planning. However, at least two findings encompass all empirical contributions in this thematic issue: (1) the difficulty to capture the temporal dimension of 'migration-led institutional change' in empirical and conceptual perspective alike, and (2) the heterogeneity and agency of non-state actors in directly and indirectly shaping change at the local level.

(1): All articles face the challenge of conceptually including the temporal dimension of migration-led institutional change. Here, in particular, long-term changes are more difficult to observe in specific actions of change agents since changing rules and norms have to be explained through a complex set of exogenous and endogenous factors. It is, as the other side of the coin, difficult to predict how stable routines of short-term institutional changes become.

The analysis of pro-migrant policies in Madrid and Barcelona reveals, on the one hand, that short-term institutional change has been actively fostered by changing the routines of police protocols. On the other hand, gaps between new policies and their enforcement opened up spaces for perpetuating old administrative routines and 
neglecting migrants' access to health care and education (Fernández-Suárez \& Espiñeira, 2021). Short-term institutional change might be fragile, in the sense that it leaves room to keep up with certain institutional routines, but it also might support change agents in creating new ones.

The long-term perspectives on institutional change first and foremost highlight that migration is often just one of the aspects influencing institutional change. The article by Budnik et al. (2021), e.g., elucidates that the decline of industrial labour and geopolitical eruptions in a small town, physically close to the former 'iron curtain' are also important drivers for institutional change. Desille and Sa'di-Ibraheem (2021) in the meantime argue that the on-going neoliberal restructuring strongly influences institutional change, pointing towards its power on framing conditions of mobility and residential or commercial displacement. However, case studies in this thematic issue also make clear that there might be no migration-induced change in urban development and planning, even if this had been demanded by migrant communities for a long time and this change would serve a city's interest (Zhuang, 2021). In the end, Huning et al. (2021) see institutional change within the field of participatory planning as a slow process which needs time to unfold structurally, but institutional change can also be fuelled through experimentation and transformative approaches like real-world laboratories.

(2): Civil society actors and economic stakeholders like neighbourhood initiatives, NGOs, Social Movements, or corporations have been important change agents in all empirical case studies in this thematic issue. Despite their heterogeneity, they have influenced migration-led institutional change in their interactions with state actors like municipal administrations. Agency, understood here as the capability to change cities and their formal and informal institutions, is strongly linked to the ability to create strong ties and networks between civil society and municipalities. Here, Bund and Gerhard (2021) show that cities with less financial resources only develop strong integration strategies if they can build on long-standing, intense networks. The case study done by Vergou et al. (2021) reveals that cities cooperating with neighbourhood initiatives and international NGOs can develop fruitful governance arrangements.

However, a difficult aspect of involving civil society actors in migration-led institutional change is raised by Fernández-Suárez and Espiñeira (2021). They analyse tensions between former activists coming to power in municipal governments and the Social Movements they had belonged to. In a different but also critical way, Hanhörster and Ramos Lobato (2021) focus on the agency of private housing companies as economic actors on migrants' access to housing. As institutional housing providers in Germany, they (re)produce socio-spatial inequalities and exclusion. In this case, non-state actors cannot be described as progressive innovators or drivers of pro-migrant policy change.
All in all, the articles in this thematic issue lead us to the question of whether migration-led institutional change can be fully understood only in the sense that it serves an emancipatory pro-migration discourse. Here, Nettelbladt's (2021) empirical work critically challenges this perspective as it looks at reconfigurations in participatory urban governance to challenge racist hegemony, which links migration-led societal transformation to fear and structural social inequalities. This possibility of xenophobic connotations or outcomes of migration-led institutional change demonstrates the struggle over its definition. A totally different perspective on questioning the positive connotation of migration-led institutional change is presented by Desille and Sa'di-Ibraheem (2021), as they decentre the progressive character of promigrant policies in the European context from a critical settler-colonial perspective in Palestine/Israel.

To conclude in a conceptual perspective, research on migration-led institutional change still has many biases and is very dependent on theoretical perspectives, positionalities of researchers, and the local context of the case studies. Also, it seems difficult to clearly define whether an observed institutional change is migration-led or supported by other factors. Here, it seems particularly promising to conduct more research on migrationled institutional change, e.g., in the Global South or postsocialist contexts. Furthermore, looking more deeply into local migration-led institutional change in a comparative perspective might help to understand not only local specificities but also the actual drivers for change.

\section{Acknowledgments}

Questions addressed in this thematic issue were discussed at the Session "Migration as a driver of institutional change," organised by the guest editors of this thematic issue. The session took place at the German Congress for Geography 2019, in Kiel, Germany. This research was funded by the German Federal Ministry of Education and Research within the project "INTERPARTIntercultural Spaces of Participation" (Grant Number 01UM1822AY).

\section{Conflict of Interests}

The authors declare no conflict of interests.

\section{References}

Budnik, M., Grossmann, K., \& Hedtke, C. (2021). Migration-related conflicts as drivers of institutional change? Urban Planning, 6(2), 103-112.

Bund, E., \& Gerhard, U. (2021). The role of institutional and structural differences for city-specific arrangements of urban migration regimes. Urban Planning, 6(2), 68-79.

Caponio, T., Scholten, P., \& Zapata-Barrero, R. (Eds.). (2018). The Routledge handbook of the gover- 
nance of migration and diversity in cities. London: Routledge.

Dekker, R., Emilsson, H., Krieger, B., \& Scholten, P. (2015). A local dimension of integration policies? A comparative study of Berlin, Malmö, and Rotterdam. International Migration Review, 49(3), 633-658.

Desille, A., \& Sa'di-Ibraheem, Y. (2021). 'It's a matter of life or death': Jewish migration and dispossession of Palestinians in Acre. Urban Planning, 6(2), 32-42.

Fernández-Suárez, B., \& Espiñeira, K. (2021). The role of the 'Cities for Change' in protecting the rights of irregular migrants in Spain. Urban Planning, 6(2), 56-67.

González, S., \& Healey, P. (2005). A sociological institutionalist approach to the study of innovation in governance capacity. Urban Studies, 42(11), 2055-2069.

Gruber, E. (2021). Can transnational cooperation support municipalities to address challenges of youth migration? Urban Planning, 6(2), 43-55.

Hanhörster, H., \& Ramos Lobato, I. (2021). Migrants' access to the rental housing market in Germany: Housing providers and allocation policies. Urban Planning, 6(2), 7-18.

Healey, P. (1999). Institutionalist analysis, communicative planning, and shaping places. Journal of Planning Education and Research, 19(2), 111-121.

Healey, P. (2007). The new institutionalism and the transformative goals of planning. In N. Verma (Ed.), Current research in urban and regional studies: Institutions and planning (pp. 61-87). Amsterdam: Elsevier.

Hu, X., \& Yang, C. (2019). Institutional change and divergent economic resilience: Path development of two resource-depleted cities in China. Urban Studies, 56(16), 3466-3485.

Huning, S., Droste, C., \& Gliemann, K. (2021). Promoting interculture in participation in German urban planning: Fields of action for institutional change. Urban Planning, 6(2), 127-138.
Jahre, S. (2021). Postmigrant spatial justice? The case of 'Berlin Develops New Neighbourhoods' (BENN). Urban Planning, 6(2), 80-90.

Jørgensen, M. B. (2012). The diverging logics of integration policy making at national and city level. International Migration Review, 46(1), 244-278.

Lang, C. (2020). Workforce diversity policies in practice: Drivers and barriers in local administrations. Ethnic and Racial Studies, 43(11), 1961-1980.

Mahoney, J., \& Thelen, K. (2010). A theory of gradual institutional change. In J. Mahoney \& K. Thelen (Eds.), Explaining institutional change (pp. 1-37). Cambridge: Cambridge University Press.

Nettelbladt, G. (2021). Disrupting dialogue? The participatory urban governance of far-right contestations in Cottbus. Urban Planning, 6(2), 91-102.

Scholten, P. (2016). Between national models and multilevel decoupling: The pursuit of multi-level governance in Dutch and UK policies towards migrant incorporation. Journal of International Migration and Integration, 17(4), 973-994.

Sorensen, A. (2011). Uneven processes of institutional change: path dependence, scale and the contested regulation of urban development in Japan. International Journal of Urban and Regional Research, 35(4), 712-734.

Streeck, W., \& Thelen, K. (Eds.). (2005). Beyond continuity: Institutional change in advanced political economies. Oxford: Oxford University Press.

Vergou, P., Arvanitidis, P. A., \& Manetos, P. (2021). Refugee mobilities and institutional changes: Local housing policies and segregation processes in Greek cities. Urban Planning, 6(2), 19-31.

Zhuang, Z. C. (2021). The negotiation of space and rights: Suburban planning with diversity. Urban Planning, 6(2), 113-126.

\section{About the Authors}

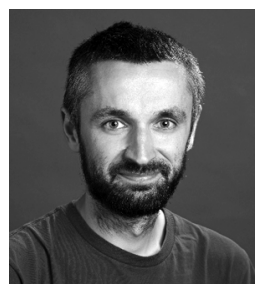

Robert Barbarino works at the Department of International Planning Studies, School of Spatial Planning, TU Dortmund University, and is doing his PhD on migration and participatory urban development at the Department of Applied Geography and Spatial Planning at Humboldt University of Berlin.

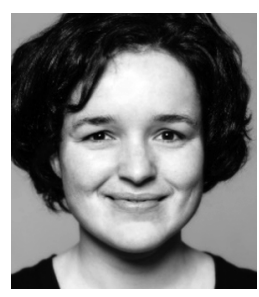

Charlotte Räuchle is affiliated with the Institute of Geographical Science, Free University Berlin, Germany. Her research interests centre on transformative urban studies, migration and urban development, migrant entrepreneurship, and comparative urban research. 


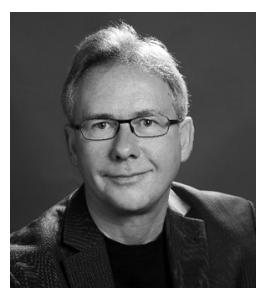

Wolfgang Scholz is an Urban Planner and Researcher. In 2006, he received his PhD in informal urbanisation in Zanzibar/Tanzania. Currently, he conducts research at TU Dortmund University on resilient urban development in Manila. He has more than 15 years of research experience in the fields of urban infrastructure, mobility, and informal urban development in the Global South, as well as teaching experience in urban design and planning theory, in both the Global North and the Global South. 